INVITED REVIEW

\title{
Androgen therapy in women
}

Wiebke Arlt

Division of Medical Sciences, Institute of Biomedical Research, Endocrinology, Room 233, University of Birmingham, Birmingham, B15 2TT, UK

(Correspondence should be addressed to W Arlt; Email: w.arlt@bham.ac.uk)

\begin{abstract}
Androgens in women either derive from direct ovarian production or from peripheral conversion of the adrenal sex steroid precursor, dehydroepiandrosterone, towards active androgens. Therefore, loss of adrenal or ovarian function, caused by Addison's disease or consequent to bilateral oophorectomy, results in severe androgen deficiency, clinically often associated with a loss of libido and energy. Importantly, physiological menopause does not necessarily lead to androgen deficiency, as androgen synthesis in the ovaries may persist despite the decline in estrogen production. However, the definition of female androgen deficiency, as recently provided by the Princeton consensus statement, is not precise enough and may lead to over-diagnosis due to the high prevalence of its diagnostic criteria: androgen levels below or within the lower quartile of the normal range and concurrent sexual dysfunction. Importantly, physiological menopause is not necessarily associated with androgen deficiency and therefore does not routinely require androgen therapy. Current replacement options include transdermal testosterone administration or dehydroepiandrosterone treatment, both of which have been shown to result in significant improvements, in particular in libido and mood, while effects on body composition and muscular function are not well documented. It is important to keep in mind that the number of randomized controlled trials is still limited and that currently none of the available preparations is officially approved for use in women. Currently, androgen replacement should be reserved for women with severe androgen deficiency due to an established cause and matching clinical signs and symptoms.
\end{abstract}

European Journal of Endocrinology 154 1-11

\section{Introduction}

The apparent link between male hormones and female sexuality has recently fuelled interest in androgen therapy in women. Female androgen deficiency has quickly evolved as a center-stage topic, both in the perception of the scientific community and, importantly, of the lay audience. This development comes shortly after the results of the Women's Heatlh Initiative have brought the concept of postmenopausal estrogen/progestin replacement to a standstill (1). However, in contrast to the proven and definitive loss of ovarian estrogen synthesis in physiological menopause, it is far from certain that the ovary invariably loses its androgenic capacity during the menopausal transition. The gap between fact and fiction in female androgen physiology is still broad and fashion terms like 'female androgen deficiency syndrome' and 'hypoactive sexual desire disorder' have provided little help with a precise definition of female androgen deficiency, but rather have contributed to a blurring of the lines. Clinical experience with androgen therapy in women is still limited, in particular with regard to randomized controlled trials.
The federal drug agency (FDA) recently denied approval of an androgen replacement tool for women because of concerns about the paucity of long-term safety data. This review seeks to summarize currently available information on androgen therapy in women and admits from the outset that there are several hitherto unresolved issues.

\section{Physiology of female androgen production}

In humans, the adrenal glands and the ovaries represent the main sources of circulating androgens in women. The adrenal steroid dehydroepiandrosterone (DHEA) represents the crucial precursor of human sex steroid biosynthesis. DHEA and its sulfate ester (DHEAS) are the most abundant steroids in the human circulation. DHEA is mainly released from the adrenal zona reticularis (2) and only desulfated DHEA, but not DHEAS, can be converted downstream towards sex steroids. Recent evidence suggests that hydrolysis of DHEAS to DHEA may be restricted to some peripheral tissues including prostate and 
mammary gland while the rate-limiting step regulating the equilibrium between DHEA and DHEAS will be DHEA sulfotransferase activity, converting DHEA to DHEAS (3). A significant amount of the total androgenic pool derives from androgen synthesis within peripheral target cells of androgen action. In addition, DHEA may serve as a prohormone for ovarian androgen synthesis (4). Figure 1 represents a schematic overview of androgen synthesis in women. Transient adrenal suppression by dexamethasone in healthy young women leads to a $90 \%$ decrease in circulating DHEA and DHEAS and also reduces circulating testosterone and dihydrotestosterone (DHT) levels to 30$40 \%$ of their respective baseline levels (5). DHEA, DHEAS and androstenedione do not have androgenic activity unless they are converted to testosterone and DHT, which can both bind and activate the androgen receptor. Testosterone can be converted either to DHT, which has a five times higher binding affinity to the androgen receptor or it can be aromatized towards estrogens. DHT cannot be aromatized. Therefore, it is important to realize that an increase in the circulating testosterone pool will invariably be associated with increased estrogen generation within peripheral target tissues of sex steroid action. In women, significant androgen production physiologically starts during adrenarche, i.e. the increase in adrenal DHEA and DHEAS production from previously non-detectable levels occurring between the 6th and 10th year of age. This leads to an increased conversion of DHEA towards active androgens in peripheral target cells like the skin, and characteristically results in the first appearance of pubic hair ('pubarche'). Adrenarche is

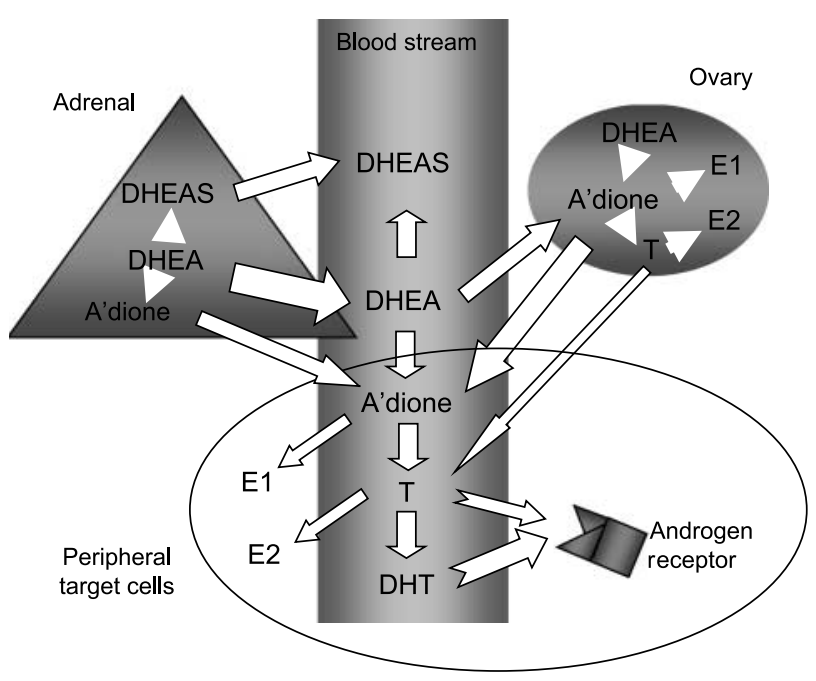

Figure 1 Schematic overview of the generation of androgen precursors and their conversion towards active androgens in women. The figure depicts the contributions of adrenal, ovary and peripheral target cells to this process. DHEA, dehydroepiandrosterone; DHEAS, DHEA sulfate; A'dione, androstenedione; T, testosterone; $\mathrm{DHT}$, dihydrotestosterone; E1, estrone; E2, 17 $\beta$-estradiol. independent of the onset of menarche. In girls who do not undergo adrenarche, ovarian maturation and folliculogenesis are not affected, but circulating androgen levels invariably remain low. The intraindividual maximum of DHEA and DHEAS production is reached in early adulthood, followed by a steady decline throughout adult life, eventually decreasing to 10$20 \%$ of previous maximum levels by 70 to 80 years of age (6-8). This age-associated decrease has been termed 'adrenopause,' in spite of the fact that adrenal glucocorticoid and mineralocorticoid secretion rates are maintained without change throughout one's lifetime. Adrenopause is independent of menopause, and it occurs in both sexes. The degree to which naturally occurring menopause affects circulating androgen levels has been a matter of debate. Studies in subjects with dexamethasone-induced adrenal suppression indicate that the resulting decrease in serum androgen levels seems to be more pronounced in postmenopausal (9) than in premenopausal women (5). This suggests that the ovarian contribution to the total androgenic pool may be lower during menopause. However, DHEA of adrenal origin may still be converted to testosterone within the postmenopausal ovary. Cross-sectional and longitudinal studies during the menopause transition found no evidence of a significant decrease in circulating androgens $(10,11)$. This was confirmed by a recent study from Australia studying a carefully selected, population-based reference sample of 595 women in whom all potential confounding variables impacting on androgen levels had been excluded (12). This extremely well designed and adequately powered study describes a gradual but modest decline in circulating androgens (testosterone, free testosterone, androstenedione and DHEAS) with age (12) (Fig. 2). However, menopause did not significantly impact on serum androgens. Thus, the ability of ovarian theca cells to synthesize androgens apparently persists after menopause, despite the loss of estrogen production in granulosa cells. This is also illustrated by the finding that bilateral oophorectomy in postmenopausal women leads to a significant decrease in circulating levels of androgens $(12,13)$.

\section{Definition of female androgen deficiency}

According to the recently published Princeton consensus statement issued by an expert panel from the United States and Australia, 'female androgen deficiency syndrome' (FADS) may be diagnosed in women who meet all of the following three criteria: first, impaired well-being or libido; secondly, adequate estrogenization (i.e. either normal ovarian function or established estrogen replacement therapy (ERT)); and thirdly, serum androgen concentrations below or within the lower quartile of the female normal range (14). However, this seems to be a rather loose definition as 


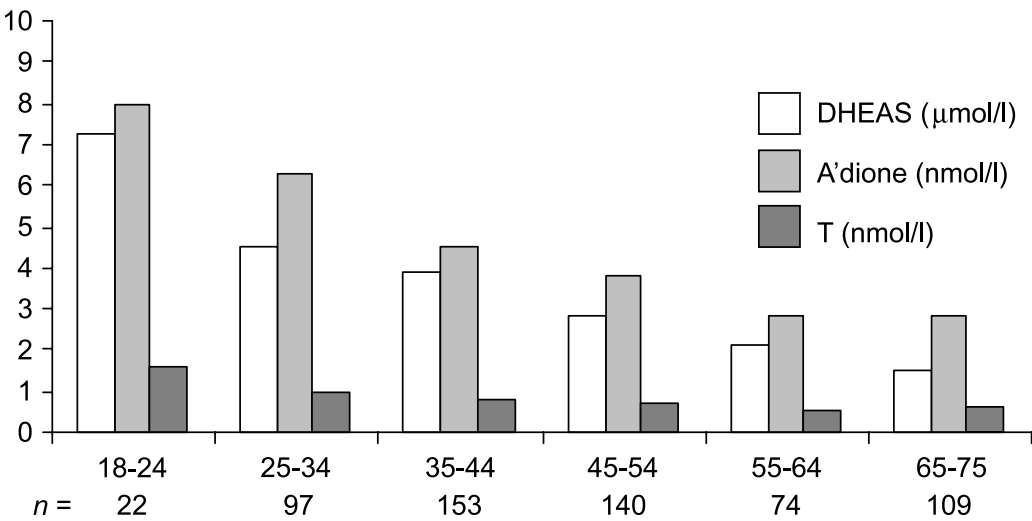

Figure 2 Serum androgens (medians) across life span in a healthy female reference cohort $(n=595)$ according to Davison et al. (12). impaired mood and libido are multi-factorial in origin and thus cannot be considered specific indicators of androgen deficiency. It does not seem feasible to consider androgen replacement for every woman with self-perceived impaired well-being, who also happens to have serum androgen concentrations within the lower quarter of the normal range. An even more problematic development is to consider the diagnostic term 'hypoactive sexual desire disorder' (HSDD) as a sufficient justification for the initiation of androgen replacement therapy. According to the consensus of the Sexual Function Health Council of the American Foundation for Urologic Disease (AFUD), comprising 19 experts from five countries, HSDD is defined by the concurrent presence of the following two criteria: first, persistent or recurrent deficiency (or absence) of sexual fantasies, thoughts, and/or desire for, or receptivity to, sexual activity and secondly, personal distress caused by the sexual dysfunction described in the first criterion (15). HSDD is obviously of multi-factorial origin and androgen deficiency is not part of its definition. If we were to base the indication for androgen therapy in women on the presence of HSDD, we would start to treat a large proportion of the general population, with recent figures indicating a 50\% incidence of female sexual dysfunction based on the AFUD criteria in gynecologic and uro-gynecologic out-patient cohorts (16). The presence of HSDD alone is certainly no justification for the initiation of androgen treatment. Importantly, a recently published cross-sectional study in a large cohort of Australian women $(n=1423)$ found no significant correlation of circulating androgen levels with self-reported perception of sexual desire and sexual satisfaction (17). Interestingly, although the majority of women with a low DHEAS did not have low sexual function, a low DHEAS (10th percentile) was still significantly associated with higher odds of impaired sexual function (17). However, no data were provided on circulating levels of biologically active, desulfated DHEA in this cohort. It is well described that circulating DHEAS can be decreased in chronic disease or stress and this may also contribute to the observed decrease in libido in those women. The data from the Australian cohort were further corroborated by the results of the recently published Study of Women's Health Across the Nation (SWAN) (18) that studied circulating androgens in a community-based cohort of 42 - to 52-year-old women $(n=2961)$. Only modest or minimal associations of testosterone with increased sexual desire and DHEAS with functional status and self-reported health were found, but androgens were most strongly associated with markers of metabolic syndrome (body mass index, waist circumference, and waist-hip ratio) (18). The currently available facts on female androgen physiology clearly suggest that women with significant, near-total depletion of androgens are the most suitable candidates for androgen replacement. Women invariably develop severe androgen deficiency following bilateral oophorectomy, confirming the important role of the ovaries as a source of active androgens. Similarly, women with adrenal insufficiency usually present with significant androgen deficiency due to the pathological loss or decrease in adrenal DHEA synthesis. Pharmacological glucocorticoid treatment, e.g. for asthma or rheumatic diseases, invariably results in suppression of adrenal DHEA synthesis following feedback inhibition of adrenocorticotropin release, and therefore is also associated with androgen deficiency. Women with one of these established causes of severe androgen deficiency and concurrent complaints of impaired well-being and libido are likely to benefit from androgen replacement therapy. Women with premature ovarian failure of autoimmune origin may also have pathologically decreased androgen levels. However, DHEA production in premature ovarian failure persists (19) and therefore androgen deficiency is less pronounced. Furthermore, premature ovarian failure may, in some cases, be associated with even increased androgen levels, possibly as a consequence of a considerable variability in the extent of destruction of androgen-producing ovarian theca cells (20). Women with Turner's syndrome may also suffer from significant androgen deficiency (21). It is important to consider the assays employed for assessment of androgen deficiency when establishing a diagnosis of severe androgen deficiency 
based on hormone measurements. Some luminometric assays used for determination of free testosterone levels may be problematic whereas radioimmunoassays (RIAs) generally are reliable. Concurrent measurement of total testosterone and sex hormone-binding globulin (SHBG) concentrations may represent an alternative when no RIA for free testosterone is available. Testosterone and SHBG levels can be used to calculate the free androgen index $(\mathrm{FAI})$, where $\mathrm{FAI}=($ testosterone $\mathrm{nmol} / \mathrm{l} \times 100) /$ SHBG $\mathrm{nmol} / \mathrm{l}(22)$. Importantly, estrogens increase SHBG concentrations, and thus decrease the FAI. Consequently, if assessing androgen deficiency in a woman treated with an oral contraceptive or estrogen replacement therapy, one should always consider first reducing the estrogen dose rather than immediately initiating androgen therapy. Furthermore, the progestin component of oral contraceptives e.g. cyproterone acetate or drospirenone, may exert anti-androgenic properties and should be exchanged for another progestin if problems like loss of libido occur.

\section{Testosterone therapy in women - pharmacokinetics and delivery tools}

Androgen replacement therapy is a challenge even when treating men, but adjusting androgen levels to the normal range in women has proven to be even more difficult. Oral testosterone preparations show a broad variability with regard to resorption. Methyltestosterone and testosterone undecanoate have short half-lives and require repeated administration. Their pharmacokinetic properties lead to supraphysiological androgen levels shortly after resorption, followed by rapid decline. Not surprisingly, some studies in which a single daily dose of methyltestosterone was used for androgen therapy in women did not detect any increase in circulating androgen levels (23). Subcutaneous testosterone depot implants have the advantage that they only need to be administered every four to six months. However, even the smallest available dose (100 mg) induces supraphysiological androgen levels for several weeks to several months after implantation (24). Recently introduced transdermal androgen patches are more convenient to use but may still have some unfavorable pharmacokinetic properties (24), sometimes resulting in supraphysiological active androgen levels in treated women (25). Optimization of a transdermal delivery system is underway which will include testosterone gel preparations already in use for men. However, it is important to bear in mind that none of the currently available options is officially approved for use in women (Table 1). Some studies have used the synthetic testosterone analog, oxandrolone, to examine the effects of androgen replacement in women with Turner's syndrome (26). This synthetic androgen has previously been used to induce growthpromoting effects in Turner's syndrome patients. Oxandrolone is a low-affinity androgen receptor agonist with 10-100 times lower activity than testosterone and DHT (27). Oxandrolone cannot be aromatized, thus its effect is mediated via the androgen receptor only. However, one disadvantage of treatment with synthetic anabolic steroids is that drug monitoring is more difficult as serum testosterone levels cannot serve as a parameter for treatment surveillance.

\section{Clinical experience with testosterone therapy in women}

Most, if not all, of the studies published to date concentrated on potential effects on female libido and wellbeing and recorded androgenic skin effects while data on lipids, insulin sensitivity, and body composition are much more scarce, and often preliminary. When interpreting the results of studies on the effects of androgen treatment in women, several methodological issues

Table 1 Delivery tools for androgen replacement used in published studies on androgen treatment in women. Note that to date none of these preparations has been officially approved for use in women.

\begin{tabular}{|c|c|c|}
\hline Preparation & Route of administration & Comments \\
\hline $\begin{array}{l}\text { Testosterone undecanoate, } \\
\text { methyltestosterone }\end{array}$ & Oral & Short half-lives, therefore multiple $(3-5)$ daily doses required \\
\hline Oxandrolone & Oral & $\begin{array}{l}\text { Synthetic testosterone analog; cannot be aromatized; treatment } \\
\text { surveillance cannot rely on testosterone measurements; } \\
\text { administration once daily }\end{array}$ \\
\hline Testosterone implants & Subcutaneous & $\begin{array}{l}\text { Long-lasting, induces supra-physiologic testosterone levels even } \\
\text { at low doses; inserted subcutaneously every } 4-6 \text { months }\end{array}$ \\
\hline Testosterone patches & Transdermal & $\begin{array}{l}\text { Different preparations with different half-lives, most favorable } \\
\text { pharmacokinetic properties of available testosterone } \\
\text { preparations; application of a transdermal patch } 2-3 \text { times } \\
\text { per week }\end{array}$ \\
\hline DHEA & Oral & $\begin{array}{l}\text { Sex steroid precursor; favorable pharmacokinetic properties; } \\
\text { currently no preparation produced according to Good } \\
\text { Pharmaceutical Practice (GPP) standards is available }\end{array}$ \\
\hline
\end{tabular}


have to be considered. First, due to the pharmacokinetic properties of available testosterone preparations most published studies on the effects of treatments are associated with supraphysiological androgen levels. Secondly, several studies were not carried out in a double-blind fashion, thus precluding proper assessment of the effects of androgens on self-perceived mood and libido. Thirdly, most of the earlier studies in this field compared the effects of conventional estrogen/progestin hormone replacement therapy (HRT) with the effects of HRT + androgens in previously untreated, symptomatic postmenopausal women. The effect of initiating estrogen treatment in these women was so dramatic that any additional benefit of androgen treatment was almost non-detectable (28). Table 2 summarizes the published studies employing testosterone treatment in women. Results of two studies that employed testosterone implants and oral methyltestosterone in addition to HRT indicated the significant beneficial effects on bone mineral density (29, 30). However, the degree to which these effects were due to aromatization, thus representing estrogen rather than androgen effects, is unclear. The effects on body composition are inconsistent, and while mostly a gain in lean body mass was reported $(31,32)$, there were reports of both a gain (32) and a loss (31) in fat mass. The small number of participants and the lack of longer-term studies currently prevent proper evaluation of the effects of testosterone treatment on body composition, bone mineral density or insulin sensitivity. Study results showing androgen effects on lipids are also heterogeneous, but androgens are consistently reported to induce a decrease in high-density lipoprotein (HDL) cholesterol levels $(29,32,33)$. Since early on, the effects of androgens on female sexuality have been the main focus of research. Beneficial effects on libido and mood were reported in both double-blind (34, 35) and single-blind (30) studies on testosterone replacement in surgically menopausal women, i.e. women with an established cause of significant androgen deficiency. However, in these studies, testosterone administration resulted in supraphysiological serum androgen concentrations. Administration of low-dose oral testosterone did not induce significant additional improvements compared with conventional ERT after 2 years of treatment in oophorectomized women (29). Shifren et al. conducted a landmark study helping to define the impact of androgens on sexuality (25). They studied the effects of transdermal testosterone replacement in 75 oophorectomized women who had impaired sexual function at baseline. Results showed that testosterone therapy had statistically significant beneficial effects on various aspects of sexuality. However, these results were only statistically significant for patients in the higher dose group $(300 \mu \mathrm{g} /$ day) associated with circulating androgen levels at or above the upper limit of the normal range (25). Most recently, three large studies on a transdermal testosterone delivery system in women with bilateral oophorectomy and concurrent sexual desire disorder have been published (36-38). The study by Braunstein et al. (36) compared 24 weeks of treatment with three doses of transdermal testosterone (150, 300 and $450 \mu \mathrm{g} /$ day $)$ with placebo treatment and established that $300 \mu \mathrm{g} /$ day significantly increased the frequency of satisfactory sexual activity and sexual desire, while $150 \mu \mathrm{g} /$ day did not result in significant improvements and $450 \mu \mathrm{g} /$ day was associated with a significantly higher incidence of androgenic skin effects. Following up on this, Buster et al. (37) and Simon et al. (38) published the results of phase III trials comprising 24 weeks of treatment with transdermal testosterone $(300 \mu \mathrm{g} /$ day $)$ or placebo in two studies with parallel design. These studies included 533 (37) and 562 women (38) respectively suffering from sexual dysfunction after bilateral oophorectomy. Both studies confirmed the efficacy of $300 \mu \mathrm{g} /$ day on sexual activity and desire; side effects included an increased frequency of mostly mild skin effects and no serious adverse events were noted. However, in a significant proportion of these women testosterone treatment resulted in supraphysiological serum concentrations of testosterone and DHT (Fig. 3A).

\section{DHEA as an alternative tool for androgen replacement in women}

DHEA may represent an elegant alternative tool for treatment of androgen deficiency in women $(2,39)$, as it is a crucial sex steroid precursor and is rapidly converted downstream towards androgens $(5,40)$. Following oral administration of DHEA to women with adrenal insufficiency who suffer from invariably low or even nondetectable androgen levels $(11,41)$, circulating levels of androgens have increased from subnormal levels to the lower end of the normal range (40, 41). Daily administration of $50 \mathrm{mg}$ DHEA has been shown to increase DHEA and androstenedione levels to the mid normal range, while testosterone and DHT were only increased to the lower limit of the normal range (41) (Fig. 3B). However, circulating levels of androstanediol glucoronide (ADG), an androgen metabolite and useful marker of androgen generation within peripheral cells, increased to the upper limit of the normal range (41) (Fig. 3B). This indicates that DHEA replacement may not affect circulating androgens as much as testosterone administration, but the androgenic effect may be similar subsequent to DHEA conversion within peripheral cells. However, the current use of DHEA is still hampered by the lack of preparations produced according to Good Pharmaceutical Practice (GPP). Several different over-the-counter preparations marketed in the USA that claim to contain $25 \mathrm{mg}$ have been shown to contain everything between 
Table 2 Randomized controlled studies on testosterone treatment in women.

\begin{tabular}{|c|c|c|c|c|c|}
\hline Reference & Subjects & Study design & Duration & Dose & Outcome (measure) \\
\hline $\begin{array}{l}\text { Sherwin \& } \\
\text { Gelfand } \\
\text { (35); } \\
\text { Sherwin } \\
\text { et al. } \\
\text { (34) }\end{array}$ & $\begin{array}{l}\text { Women with surgical } \\
\text { menopause }(n=53)\end{array}$ & $\begin{array}{l}\text { Randomized, double-blind, } \\
\text { placebo-controlled, } \\
\text { crossover study }\end{array}$ & $\begin{array}{l}3 \\
\text { months }\end{array}$ & $\begin{array}{l}\text { Group 1: estrogen only } \\
\text { Group 2: TE } 150 \mathrm{mg} \\
\text { Group 3: estrogen + TE } 150 \mathrm{mg} \\
\text { Group 4: placebo monthly i.m. injections } \\
\text { of TE }\end{array}$ & Increase in sexual desire, arousal and fantasies \\
\hline $\begin{array}{l}\text { Myers et al. } \\
\text { (23) }\end{array}$ & $\begin{array}{l}\text { Women with physiological } \\
\text { menopause }(n=40)\end{array}$ & $\begin{array}{l}\text { Randomized, double-blind, } \\
\text { placebo-controlled, parallel } \\
\text { study }\end{array}$ & $\begin{array}{l}10 \\
\text { weeks }\end{array}$ & $\begin{array}{l}\text { Group 1: CEE } 0.625 \mathrm{mg} / \text { day }(n=10) \\
\text { Group 2: CEE + MPA } 5 \mathrm{mg} / \mathrm{day} \\
(n=10) \text { Group 3: CEE + MPA + MT } \\
5 \mathrm{mg} / \text { day }(n=10) \\
\text { Group 4: placebo }(n=10)\end{array}$ & $\begin{array}{l}\text { Increased pleasure from masturbation } \uparrow \text {, no changes } \\
\text { in mood, sexual behavior and sexual arousal (caveat: } \\
\text { normal sexual function at baseline, no ERT prior to } \\
\text { study) }\end{array}$ \\
\hline $\begin{array}{l}\text { Davis et al. } \\
\text { (30) }\end{array}$ & $\begin{array}{l}\text { Women with physiological } \\
\text { menopause }(n=34)\end{array}$ & $\begin{array}{l}\text { Randomized, single-blind, } \\
\text { placebo-controlled, parallel } \\
\text { study }\end{array}$ & $\begin{array}{l}12 \\
\text { months }\end{array}$ & $\begin{array}{l}\text { Group 1: T implants } 50 \mathrm{mg} \text { plus } \\
\text { estradiol implants } 50 \mathrm{mg} \\
\text { Group 2: estradiol implants only; three- } \\
\text { monthly s.c. insertion }\end{array}$ & $\begin{array}{l}\text { Bone mineral density (whole body, trochanter, lumbar } \\
\text { spine) } \uparrow(D X A) ; \text { increase in sexual activity, } \\
\text { satisfaction, pleasure, and orgasm }\end{array}$ \\
\hline $\begin{array}{l}\text { Watts et al. } \\
\text { (52) }\end{array}$ & $\begin{array}{l}\text { Women with surgical } \\
\text { menopause }(n=66)\end{array}$ & $\begin{array}{l}\text { Randomized, double-blind, } \\
\text { placebo-controlled, parallel } \\
\text { study }\end{array}$ & $\begin{array}{l}24 \\
\text { months }\end{array}$ & $\begin{array}{l}\text { Group 1: CEE } 0.625 \mathrm{mg} / \text { day } \\
\text { Group 2: CEE } 0.625 \mathrm{mg} / \mathrm{day}+\mathrm{MT} \\
2.5 \mathrm{mg} / \text { day }\end{array}$ & $\begin{array}{l}\text { Bone mineral density (lumbar spine) } \uparrow \text {; HDL } \\
\text { cholesterol } \downarrow \text {, triglycerides } \downarrow\end{array}$ \\
\hline $\begin{array}{l}\text { Raisz et al. } \\
\text { (53) }\end{array}$ & $\begin{array}{l}\text { Women with physiological } \\
\text { menopause }(n=28)\end{array}$ & $\begin{array}{l}\text { Randomized, double-blind, } \\
\text { placebo-controlled, parallel } \\
\text { study }\end{array}$ & 9 weeks & $\begin{array}{l}\text { Group 1: CEE } 1.25 \mathrm{mg}+\mathrm{MT} \\
2.5 \mathrm{mg} / \text { day }(n=13) \\
\text { Group 2: CEE only }(n=15)\end{array}$ & $\begin{array}{l}\text { Bone formation markers } \uparrow \text { (osterocalcin, bone alkaline } \\
\text { phosphatase, C-terminal procollagen peptide I); HDL } \\
\text { cholesterol } \downarrow \text {, triglycerides } \downarrow\end{array}$ \\
\hline $\begin{array}{l}\text { Miller et al. } \\
\text { (54) }\end{array}$ & $\begin{array}{l}\text { Women with AIDS wasting } \\
\text { syndrome }(n=53) \\
(37 \pm 1 \mathrm{yrs})\end{array}$ & $\begin{array}{l}\text { Randomized, double-blind, } \\
\text { placebo-controlled, parallel } \\
\text { study }\end{array}$ & $\begin{array}{l}12 \\
\text { weeks }\end{array}$ & $\begin{array}{l}\text { Transdermal T patches } \\
\text { Group 1: } 150 \mu \mathrm{g} / \text { day }(n=14) \\
\text { Group 2: } 300 \mu \mathrm{g} / \text { day }(n=18) \\
\text { Group 3: placebo }(n=13)\end{array}$ & $\begin{array}{l}\text { Slight but significant improvements in body weight and } \\
\text { subjective health perception in the } 300 \mu \mathrm{g} \text { dose group; } \\
\text { lean body mass } \rightarrow\end{array}$ \\
\hline $\begin{array}{l}\text { Shifren et al. } \\
\text { (25) }\end{array}$ & $\begin{array}{l}\text { Women with bilateral } \\
\text { oophorectomy and impaired } \\
\text { sexuality }(n=75) \\
\text { (35-56 yrs) }\end{array}$ & $\begin{array}{l}\text { Randomized, double-blind, } \\
\text { placebo-controlled, } \\
\text { crossover study }\end{array}$ & $\begin{array}{l}12 \\
\text { weeks }\end{array}$ & $\begin{array}{l}\text { Transdermal T patches } \\
\text { Group 1: CEE } 0.625 \mathrm{mg}+\mathrm{T} 150 \mu \mathrm{g} / \text { day } \\
\text { Group 2: CEE } 0.625 \mathrm{mg}+\mathrm{T} 300 \mu \mathrm{g} / \text { day } \\
\text { Group 3: CEE } 0.625 \mathrm{mg}+\text { placebo }\end{array}$ & $\begin{array}{l}\text { Increase in sexual activity, pleasure, orgasm, fantasies } \\
\text { and self-perceived well-being in the } 300 \mu \mathrm{g} \text { dose group } \\
\text { (caveat. slightly supraphysiological serum T and DHT) }\end{array}$ \\
\hline $\begin{array}{l}\text { Dobs et al. } \\
\text { (31) }\end{array}$ & $\begin{array}{l}\text { Women with physiological } \\
\text { menopause }(n=36)\end{array}$ & $\begin{array}{l}\text { Randomized, double-blind, } \\
\text { placebo-controlled, parallel } \\
\text { study }\end{array}$ & $\begin{array}{l}16 \\
\text { weeks }\end{array}$ & $\begin{array}{l}\text { EE } 1.25 \mathrm{mg} / \text { day }(n=18) \text { vs EE }+ \text { MT } \\
2.5 \mathrm{mg} / \text { day }(n=18)\end{array}$ & $\begin{array}{l}\text { Increased sexual activity and pleasure; Lean body } \\
\text { mass } \uparrow, \text { percentage body fat } \downarrow \text { (DXA); body weight } \\
\uparrow ; \text { lower body strength } \uparrow \text {, upper body strength } \rightarrow\end{array}$ \\
\hline $\begin{array}{l}\text { Braunstein } \\
\text { et al. (36) }\end{array}$ & $\begin{array}{l}\text { Women with surgical } \\
\text { menopause }(n=447)\end{array}$ & $\begin{array}{l}\text { Randomized, double-blind, } \\
\text { placebo-controlled, parallel } \\
\text { study }\end{array}$ & $\begin{array}{l}24 \\
\text { weeks }\end{array}$ & $\begin{array}{l}\text { Transdermal T patches } \\
\text { Group 1: ERT + T } 150 \mu \mathrm{g} / \text { day }(n=107) \\
\text { Group 2: ERT + T } 300 \mu \mathrm{g} / \text { day }(n=110) \\
\text { Group 3: ERT + T } 450 \mu \mathrm{g} / \text { day }(n=111) \\
\text { Group 4: ERT + placebo }(n=119)\end{array}$ & $\begin{array}{l}\text { Significantly increased frequency of satisfying sexual } \\
\text { activity and sexual desire in the } 300 \text { and } 450 \mu \mathrm{g} \text { dose } \\
\text { groups; increased androgenic skin side effects in the } \\
450 \mu \mathrm{g} \text { dose group }\end{array}$ \\
\hline $\begin{array}{l}\text { Buster et al. } \\
\text { (37) }\end{array}$ & $\begin{array}{l}\text { Women with surgical } \\
\text { menopause }(n=447)\end{array}$ & $\begin{array}{l}\text { Randomized, double-blind, } \\
\text { placebo-controlled, parallel } \\
\text { study }\end{array}$ & $\begin{array}{l}24 \\
\text { weeks }\end{array}$ & $\begin{array}{l}\text { Transdermal T patches } \\
\text { Group 1: ERT + T } 300 \mu \mathrm{g} / \text { day } \\
\text { Group 2: ERT + placebo }\end{array}$ & $\begin{array}{l}\text { Significantly increased frequency of satisfying sexual } \\
\text { activity and sexual desire; significant incidence of } \\
\text { androgenic skin side effects, no serious adverse } \\
\text { events }\end{array}$ \\
\hline $\begin{array}{l}\text { Simon et al. } \\
\text { (38) }\end{array}$ & $\begin{array}{l}\text { Women with surgical } \\
\text { menopause }(n=447)\end{array}$ & $\begin{array}{l}\text { Randomized, double-blind, } \\
\text { placebo-controlled, parallel } \\
\text { study }\end{array}$ & $\begin{array}{l}24 \\
\text { weeks }\end{array}$ & $\begin{array}{l}\text { Transdermal T patches } \\
\text { Group 1: ERT + T } 300 \mu \mathrm{g} / \text { day } \\
\text { Group 2: ERT + placebo }\end{array}$ & $\begin{array}{l}\text { Significantly increased frequency of satisfying sexual } \\
\text { activity and sexual desire; significant incidence of } \\
\text { androgenic skin side effects, no serious adverse } \\
\text { events }\end{array}$ \\
\hline
\end{tabular}

T, testosterone; MT, methyltestosterone; TE, testosterone enanthate; CEE, conjugated equine estrogens; EE, esterified estrogen; MPA, medroxyprogesterone acetate; ERT, estrogen replacement therapy; DXA, Dual-energy X-ray absorptionetry; HDL, high density lipoprotein 

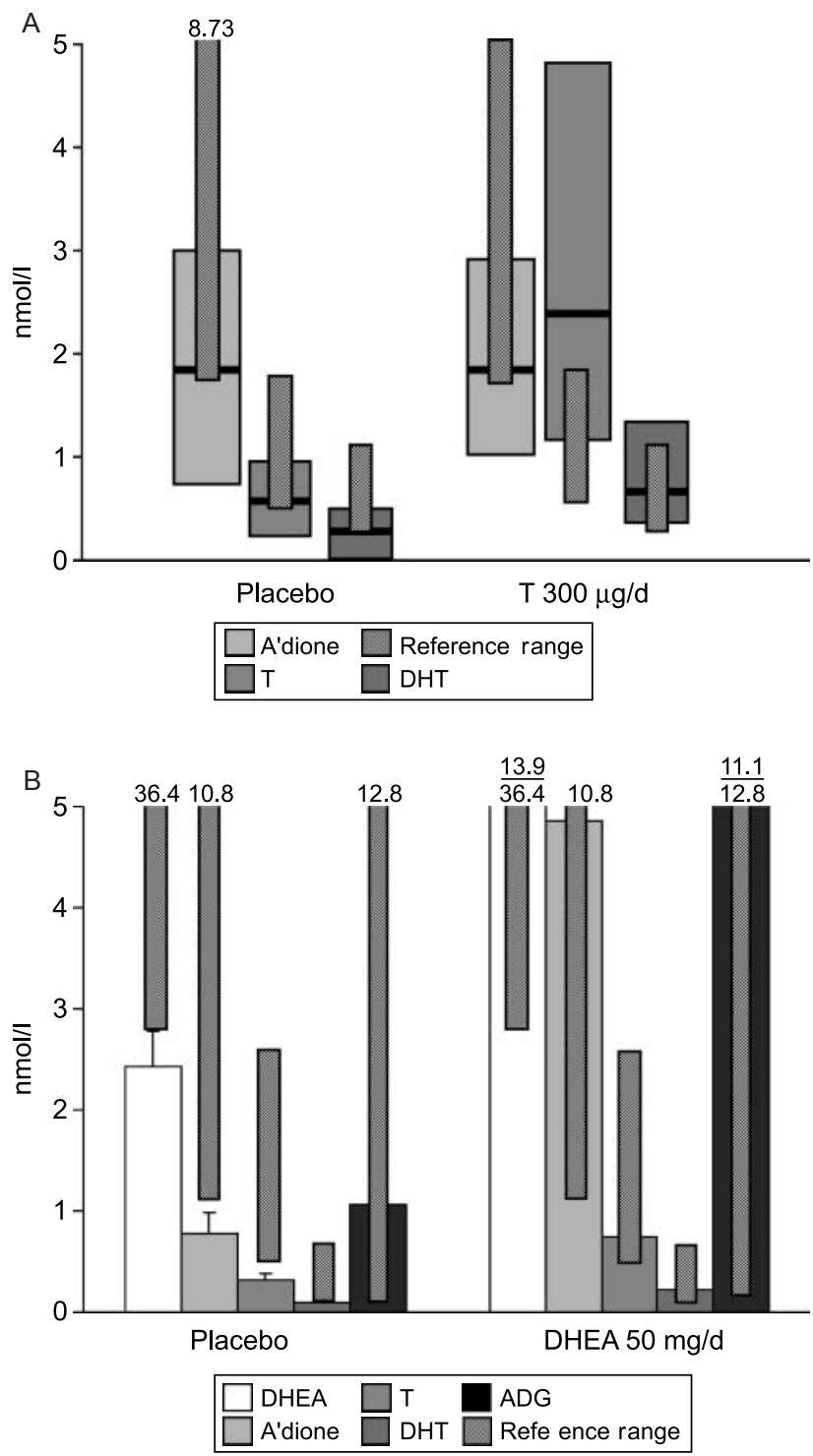

Figure 3 Effects of androgen replacement on circulating androgen concentrations. (A) Serum androstenedione (A'dione), total testosterone $(\mathrm{T})$ and dihydrotestosterone (DHT) (all medians, 10th-90th percentile) after 24 weeks of treatment with transdermal testosterone at a dose of $300 \mu \mathrm{g} /$ day in surgically menopausal women $(n=283)$ compared with placebo treatment $(n=279)$, as reported by Simon et al. (38). (B): Serum DHEA, androstenedione (A'dione), total testosterone $(\mathrm{T})$, dihydrotestosterone $(\mathrm{DHT})$ and androstanediol glucuronide (ADG) (all means + S.D.) after 4 months of treatment with placebo or DHEA at a dose of $50 \mathrm{mg} /$ day in 24 women with adrenal insufficiency, as reported by Arlt et al. (41). Underlined values at the top of the columns are the actual maximal hormone values measured; italicized values are the upper normal values of the reference range.

0 and $140 \mathrm{mg}$ (42). There are ongoing efforts to account for DHEA as a drug and not as a food supplement. However, recent legislatory changes affecting the over-the-counter sale of anabolic steroids in the USA did specifically exclude DHEA, most likely following lobbying by companies with monetary interests in the huge 'anti-aging' market sales in the United States. Women with adrenal insufficiency suffer from pronounced impairment of well-being and mood (43), and DHEA replacement in these patients has been shown to improve libido (41) as well as mood and well-being $(41,44,45)$. Table 3 summarizes the published studies employing DHEA therapy in women. By contrast, women with physiological menopause and intact adrenals did not show improvement in mood or self-perceived well-being following DHEA therapy (46). In general, the effects of DHEA replacement on mood may be more complex than those of testosterone replacement, as DHEA also potentially exerts direct neurosteroidal effects at gamma-aminobutyric acid and N-methyl-D-aspartate receptors, suggestive of a potential anti-depressive action (39), which has been demonstrated in women with midlife-onset dysthymia, significantly benefiting from DHEA replacement $(47,48)$. In the largest study published on the use of DHEA in elderly women (60 to 79 years old), comparing 12 months of treatment with DHEA $(n=70)$ vs placebo $(n=70)$, modest increases in libido and bone mineral density were observed, but only in the subgroup of women older than 70 years of age (49). There are very consistent reports of significant decreases in HDL cholesterol following DHEA replacement. Two recent studies reported an improvement in some parameters of insulin sensitivity following 12 weeks of DHEA replacement in adrenal insufficiency (50) and six months of DHEA in elderly women (51). The latter study also reported a significant decrease in fat mass as assessed by magnetic resonance imaging (MRI) in 14 women treated for six months (51).

\section{Side effects of androgen treatment in women}

The FDA has recently denied the approval of a transdermal androgen delivery system for use in women, based on its concerns about the lack of long-term safety data. Most commonly reported side effects are androgen skin effects (increased sebum secretion, greasy skin and hair, scalp itching, alopecia, hirsutism) (Tables 2 and 3). The long-term impact of unfavorable changes in cardiovascular risk markers such as the decrease in HDL cholesterol cannot be properly judged based on currently available data. This would also have to be weighed against potential beneficial effects on body composition and insulin sensitivity. However, convincing data on these effects are still lacking. There is clearly the urgent need for more long-term trials to allow for more appropriate assessment not only of the aspect of long-term safety in female androgen replacement but also on its potential beneficial effects. 


\section{Studies in women with adrenal insufficienc}

Arlt et al. (41); Women with primary $(n=14)$ and (55) (23-59 yrs)

Randomized, double-blind,

Hunt et al. (44) Women with primary adrena insufficiency (26-59yrs) $(n=24)$

Johannsson Women with secondary adrenal et al. (45) insufficiency due to hypopituitarism $(25-65 \mathrm{yrs})(n=38)$

Lovas et al. Women with primary adrenal (56) insufficiency $(n=39)$

Dhatariya et al. Women with adrenal insufficiency (50) $n=28$

Studies in healthy peri- and postmenopausal wome Morales et al. Healthy women (40-70 yrs) ( $n=17$; 15/17 menopausal, 8/15 on HRT)

Yen et al. (58); Women with physiological menopause Morales et al. $\quad(40-70 \mathrm{yrs})(n=8 ; 7 / 8$ on HRT) (59)

\section{Casson et al. Women with physiological menopause} (60) $(n=13)$ and low serum DHEAS

Barnhart et al. Perimenopausal women (45-55yrs) (46) reporting impaired well-being $(n=60)$

Baulieu et al. Postmenopausal women (60-79yrs) $(49)$ $(n=140)$

Lasco et al. Women with physiological menopause $(61)$ and low DHEAS $(n=20)$

Villareal \& Postmenopausal women (65-78yrs) Holloszy $(51) \quad(n=28)$

\section{placebo-controlled,}

crossover study

Randomized, double-blind placebo-controlled, crossover study

Randomized, double-blind, placebo-controlled,

crossover study

Randomized, double-

blind,placebo-controlled,

parallel study

Randomized, double-blind, placebo-controlled, crossover study

Randomized, double-blind, placebo-controlled,

crossover study

Randomized, double-blind placebo-controlled, crossover study

Randomized, double-blind placebo-controlled, paralle study

Randomized, double-blind, placebo-controlled, paralle study

Randomized, double-blind placebo-controlled, paralle study

Randomized, double-blind placebo-controlled, paralle study placebo-controlled, paralle study
Randomized, double-blind,
DHEA $50 \mathrm{mg} /$ day vs placebo for 4 months each $(n=24)$

DEA $50 \mathrm{mg} /$ day vs placebo for 3 months each $(n=24)$

DHEA $20-30 \mathrm{mg} /$ day v placebo for 6 months each $(n=38)(20 \mathrm{mg}>45 \mathrm{yrs} ; 30$ $\mathrm{mg}<45 \mathrm{yrs})$

DHEA $25 \mathrm{mg} /$ day $(n=19)$ vs placebo $(n=20)$ for $9 \mathrm{mon}$

DHEA $50 \mathrm{mg} /$ day vs placebo for 12 weeks each $(n=28)$

DHEA $50 \mathrm{mg} /$ day vs placebo for 3 months each $(n=17)$

DHEA $100 \mathrm{mg} /$ day vs placebo for 6 months each $(n=8)$

DHEA $25 \mathrm{mg} /$ day $(n=7)$ vs placebo $(n=6)$ for 6 month

DHEA $50 \mathrm{mg} /$ day $(n=30)$ vs placebo $(n=30)$ for 3 months

DHEA $50 \mathrm{mg} /$ day $(n=70)$

vs placebo $(n=70)$ for

2 month

DHEA $50 \mathrm{mg} /$ day $(n=10)$ vs

placebo $(n=10)$ for 12 month

DHEA $50 \mathrm{mg} /$ day $(n=14)$ vs placebo $(n=14)$ for 6 months
Increased well-being and mood, specific improvements in anxiety and depression; increased sexual interest and satisfaction; HDL $\downarrow$, LDL $\rightarrow$, Trigl. $\rightarrow$, Lpa $\rightarrow$; fasting glucose $\rightarrow$, fasting insulin $\rightarrow$, serum leptin $\downarrow$; BC $\rightarrow$ (bioimpedance); exercise capacity $\rightarrow$ (incremental cycling test); serum osteocalcin $\uparrow$, urinary crosslinks $\rightarrow$ Self-esteem $\uparrow$, mood $\uparrow$, fatigue $\downarrow$, cognition $\rightarrow$, no change in sexual function; no change in $\mathrm{BC}$ and $\mathrm{BMD}$ $(\mathrm{DXA}) ; \mathrm{HDL} \rightarrow$, LDL $\rightarrow$, Trigl. $\rightarrow$; insulin sensitivity $\rightarrow$ (fasting glucose, insulin, (HOMA);

Alertness $\uparrow$, stamina $\uparrow$, initiative $\uparrow$, improved sexual relations (validated partner questionnaire); no change in BMD (DXA); HDL $\downarrow$, ApoA1

No change in subjective health status, fatigue and sexuality; HDL $\rightarrow$; sweat odor $\uparrow$, scalp itching $\uparrow$

Insulin sensitivity $\uparrow$ (euglycemic-hyperinsulinemic clamp); plasma lipid profile (HDL $\downarrow$, LDL $\downarrow$, Trigl. $\downarrow$ )

Improved self-reported well-being $\uparrow$ (caveat: no assessment with validated questionnaires); no change in libido; no change in BMI and body fat (bio-impedance); insulin sensitivity $\rightarrow$ (ivGTT + MINMOD); HDL $\downarrow$

Basal metabolic rate $\rightarrow$ (indirect calorimetry) fasting insulin $\rightarrow$; fasting glucose $\rightarrow$, HDL $\downarrow$, ApoA $1 \downarrow$; no change in BC and BMD (DXA); urinary crosslinks $\rightarrow$ no change in muscle strength (isometric testing) No change in $B C$ and BMD (DXA); urinary crosslinks $\rightarrow$, insulin sensitivity $\rightarrow$ (iv insulin tolerance test + MINMOD); LDL $\rightarrow$, Trigl. $\rightarrow$, HDL $\downarrow$, ApoA1 No change in mood, self-perceived quality of life,

BMD $\uparrow$ in women $>70$ yrs (DXA), osteocalcin $\rightarrow$; libido $\uparrow$ in women $>70 \mathrm{yrs}$ (visual analog scale); skin sebum secretion $\uparrow$ in women $60-79$ yrs

HDL $\uparrow$, LDL $\downarrow$, Trigl. $\downarrow$; oGTT $\rightarrow$; insulin sensitivity $\uparrow$ (euglycemic hyperinsulinemic clamp)

Decrease in both visceral and subcutaneous abdominal fat (MRI); oGTT; AUC insulin $\downarrow$, AUC glucose $\rightarrow$, insulin sensitivity $\downarrow$

BC, body composition; BMD, bone mineral density; DXA, dual-energy x-ray absorptiometry; oGTT, oral glucose tolerance test; ivGTT, intravenous glucose tolerance test; AUC, area under the curve; HDL, high density lipoprotein; LDL, low density lipoprotein, Trigl., triglycerides; LPA, lipoprotein a; HOMA, homeostasis model of assessment; ApoA1, apolipoprotein A1; HRT, hormone replacement therapy; BMI, body mass index; MINMOD, Bergman minimal model. 


\section{Conclusions}

Choosing both a convenient and efficient mode of androgen administration in women remains a challenge and currently none of the available preparations is officially approved for use in women, although this is likely to change in the near future. It will be key to achieving a more precise diagnostic consenus for female androgen deficiency and to provide answers to the questions 'whom to treat, why, when and for how long'. Androgen replacement seems to be a promising option for the treatment of women with established causes of severe androgen deficiency including surgical menopause or adrenal insufficiency, if they concurrently suffer from symptoms of impaired mood and libido. In addition, the therapeutic potential of androgen replacement in women receiving chronic pharmacological glucocorticoid treatment and women with Turner's syndrome may deserve further exploration. Importantly, impairment of libido is multi-factorial in origin and in the majority of cases is not associated with evidence of androgen deficiency. Therefore, the diagnosis of hypoactive sexual desire disorder does not automatically lead to justification of androgen replacment, as androgen deficiency is not necessarily associated with this condition. It is important to acknowledge that physiological menopause in women with intact ovaries is not associated with a sudden loss of androgen synthesis, unlike the steep drop in ovarian estrogen production. Therefore, postmenopausal women do not routinely require androgen replacement. The slow, age-associated decline in DHEA, DHEAS and active androgens observed over a woman's lifetime does not represent an indication for replacement per se but may well represent a physiological, protective mechanism e.g. preventing increased sex steroid action in breast tissue. More long-term studies in larger cohorts of women with severe androgen deficiency are needed comprehensively to assess both potential beneficial and adverse effects.

\section{Acknowledgements}

This work was supported by the Medical Research Council UK (Senior Clinical Fellowship G116/172, to W A).

\section{References}

1 Rossouw JE, Anderson GL, Prentice RL, LaCroix AZ, Kooperberg C, Stefanick ML, Jackson RD, Beresford SA, Howard BV, Johnson KC, Kotchen JM \& Ockene J. Risks and benefits of estrogen plus progestin in healthy postmenopausal women: principal results From the Women's Health Initiative randomized controlled trial. Journal of the American Medical Association 2002288 321-333.

2 Allolio B \& Arlt W. DHEA treatment: myth or reality? Trends in Endocrinology and Metabolism 200213 288-294.

3 Hammer F, Subtil S, Lux P, Maser-Gluth C, Stewart PM, Allolio B $\&$ Arlt W. No evidence for hepatic conversion of dehydroepiandrosterone (DHEA) sulfate to DHEA: in vivo and in vitro studies.
Journal of Clinical Endocrinology and Metabolism 200590 36003605.

4 Haning RV Jr, Austin CW, Carlson IH, Kuzma DL \& Zweibel WJ. Role of dehydroepiandrosterone sulfate as a prehormone for ovarian steroidogenesis. Obstetrics and Gynecology 198565 199-205.

5 Arlt W, Justl HG, Callies F, Reincke M, Hubler D, Oettel M, Ernst M, Schulte HM \& Allolio B. Oral dehydroepiandrosterone for adrenal androgen replacement: pharmacokinetics and peripheral conversion to androgens and estrogens in young healthy females after dexamethasone suppression. Journal of Clinical Endocrinology and Metabolism $1998 \mathbf{8 3} 1928-1934$.

6 Orentreich N, Brind JL, Rizer RL \& Vogelman JH. Age changes and sex differences in serum dehydroepiandrosterone sulfate concentrations throughout adulthood. Journal of Clinical Endocrinology and Metabolism 198459 551-555.

7 Orentreich N, Brind JL, Vogelman JH, Andres R \& Baldwin H. Long-term longitudinal measurements of plasma dehydroepiandrosterone sulfate in normal men. Journal of Clinical Endocrinology and Metabolism 199275 1002-1004.

8 Arlt W. Dehydroepiandrosterone and ageing. Best Practice $\mathcal{E}$ Research in Clinical Endocrinology \& Metabolism 2004 $18363-380$.

9 Couzinet B, Meduri G, Lecce MG, Young J, Brailly S, Loosfelt H, Milgrom E \& Schaison G. The postmenopausal ovary is not a major androgen-producing gland. Journal of Clinical Endocrinology and Metabolism 200186 5060-5066.

10 Burger HG. Androgen production in women. Fertility \& Sterility 200277 (Suppl 4) S3-S5.

11 Miller KK, Sesmilo G, Schiller A, Schoenfeld D, Burton S \& Klibanski A. Androgen deficiency in women with hypopituitarism. Journal of Clinical Endocrinology and Metabolism $20018 \mathbf{8 6}$ 561-567.

12 Davison S, Bell R, Donath S, Montalto J \& Davis S. Androgen levels in adult females: changes with age, menopause and oophorectomy. Journal of Clinical Endocrinology and Metabolism 200590 $3847-3853$.

13 Laughlin GA, Barrett-Connor E, Kritz-Silverstein D \& von Muhlen D. Hysterectomy, oophorectomy, and endogenous sex hormone levels in older women: the Rancho Bernardo Study. Journal of Clinical Endocrinology and Metabolism 200085 645-651.

14 Bachmann G, Bancroft J, Braunstein G, Burger H, Davis S, Dennerstein L, Goldstein I, Guay A, Leiblum S, Lobo R, Notelovitz M, Rosen R, Sarrel P, Sherwin B, Simon J, Simpson E, Shifren J, Spark R \& Traish A. Female androgen insufficiency: the Princeton consensus statement on definition, classification, and assessment. Fertility and Sterility 200277 660-665.

15 Basson R, Berman J, Burnett A, Derogatis L, Ferguson D, Fourcroy J, Goldstein I, Graziottin A, Heiman J, Laan E, Leiblum S, Padma-Nathan H, Rosen R, Segraves K, Segraves RT, Shabsigh R, Sipski M, Wagner G \& Whipple B. Report of the international consensus development conference on female sexual dysfunction: definitions and classifications. Journal of Urology 2000 $163888-893$.

16 Geiss IM, Umek WH, Dungl A, Sam C, Riss P \& Hanzal E. Prevalence of female sexual dysfunction in gynecologic and urogynecologic patients according to the international consensus classification. Urology $2003 \mathbf{6 2} 514-518$.

17 Davis SR, Davison SL, Donath S \& Bell RJ. Circulating androgen levels and self-reported sexual function in women. Journal of the American Medical Association 2005294 91-96.

18 Santoro N, Torrens J, Crawford S, Allsworth JE, Finkelstein JS, Gold EB, Korenman S, Lasley WL, Luborsky JL, McConnell D, Sowers MF \& Weiss G. Correlates of Circulating Androgens in Mid-Life Women: the Study of Women's Health Across the Nation (SWAN). Journal of Clinical Endocrinology and Metabolism $2005904836-4845$.

19 Benetti-Pinto CL, Bedone AJ \& Magna LA. Evaluation of serum androgen levels in women with premature ovarian failure. Fertility and Sterility $200583508-510$.

20 Bachelot A, Meduri G, Massin N, Misrahi M, Kuttenn F \& Touraine P. Ovarian steroidogenesis and serum androgen levels 
in patients with premature ovarian failure. Journal of Clinical Endocrinology and Metabolism 200590 2391-2396.

21 Gravholt CH, Svenstrup B, Bennett P \& Christiansen JS. Reduced androgen levels in adult turner syndrome: influence of female sex steroids and growth hormone status. Clinical Endocrinology 1999 50 791-800.

22 Bancroft J \& Cawood EH. Androgens and the menopause; a study of 40-60-year-old women. Clinical Endocrinology $1996 \mathbf{4 5}$ $577-587$.

23 Myers LS, Dixen J, Morrissette D, Carmichael M \& Davidson JM. Effects of estrogen, androgen, and progestin on sexual psychophysiology and behavior in postmenopausal women. Journal of Clinical Endocrinology and Metabolism 199070 1124-1131.

24 Buckler HM, Robertson WR \& Wu FC. Which androgen replacement therapy for women? Journal of Clinical Endocrinology and Metabolism 199883 3920-3924.

25 Shifren JL, Braunstein GD, Simon JA, Casson PR, Buster JE, Redmond GP, Burki RE, Ginsburg ES, Rosen RC, Leiblum SR, Caramelli KE \& Mazer NA. Transdermal testosterone treatment in women with impaired sexual function after oophorectomy New England Journal of Medicine 2000343 682-688.

26 Ross JL, Roeltgen D, Stefanatos GA, Feuillan P, Kushner H, Bondy C \& Cutler GB Jr. Androgen-responsive aspects of cognition in girls with Turner syndrome. Journal of Clinical Endocrinology and Metabolism 200388 292-296.

27 Kemppainen JA, Langley E, Wong CI, Bobseine K, Kelce WR \& Wilson EM. Distinguishing androgen receptor agonists and antagonists: distinct mechanisms of activation by medroxyprogesterone acetate and dihydrotestosterone. Molecular Endocrinology 1999 $13440-454$.

28 Montgomery JC, Appleby L, Brincat M, Versi E, Tapp A, Fenwick PB \& Studd JW. Effect of oestrogen and testosterone implants on psychological disorders in the climacteric. Lancet $19871297-299$.

29 Barrett-Connor E, Young R, Notelovitz M, Sullivan J, Wiita B, Yang HM \& Nolan J. A two-year, double-blind comparison of estrogen-androgen and conjugated estrogens in surgically menopausal women. Effects on bone mineral density, symptoms and lipid profiles. Journal of Reproductive Medicine $1999 \mathbf{4 4}$ $1012-1020$

30 Davis SR, McCloud P, Strauss BJ \& Burger H. Testosterone enhances estradiol's effects on postmenopausal bone density and sexuality. Maturitas 199521 227-236.

31 Dobs AS, Nguyen T, Pace C \& Roberts CP. Differential effects of oral estrogen versus oral estrogen-androgen replacement therapy on body composition in postmenopausal women. Journal of Clinical Endocrinology and Metabolism 200287 1509-1516.

32 Lovejoy JC, Bray GA, Bourgeois MO, Macchiavelli R, Rood JC, Greeson C \& Partington C. Exogenous androgens influence body composition and regional body fat distribution in obese postmenopausal women - a clinical research center study. Journal of Clinical Endocrinology and Metabolism $1996812198-2203$.

33 Buckler HM, McElhone K, Durrington PN, Mackness MI, Ludlam CA \& Wu FC. The effects of low-dose testosterone treatment on lipid metabolism, clotting factors and ultrasonographic ovarian morphology in women. Clinical Endocrinology 199849 $173-178$

34 Sherwin BB, Gelfand MM \& Brender W. Androgen enhances sexual motivation in females: a prospective, crossover study of sex steroid administration in the surgical menopause. Psychosomatic Medicine 198547 339-351.

35 Sherwin BB \& Gelfand MM. Sex steroids and affect in the surgical menopause: a double-blind, cross-over study. Psychoneuroendocrinology $198510325-335$.

36 Braunstein GD, Sundwall DA, Katz M, Shifren JL, Buster JE, Simon JA, Bachman G, Aguirre OA, Lucas JD, Rodenberg C, Buch A \& Watts NB. Safety and efficacy of a testosterone patch for the treatment of hypoactive sexual desire disorder in surgically menopausal women: a randomized, placebo-controlled trial. Archives of Internal Medicine 2005165 1582-1589.
37 Buster JE, Kingsberg SA, Aguirre O, Brown C, Breaux JG, Buch A, Rodenberg CA, Wekselman K \& Casson P. Testosterone patch for low sexual desire in surgically menopausal women: a randomized trial. Obstetrics and Gynecology 2005105 944-952.

38 Simon J, Braunstein G, Nachtigall L, Utian W, Katz M, Miller SS, Waldbaum AS, Bouchard C, Derzko C, Buch A, Rodenberg C, Lucas J \& Davis S. Testosterone Patch Increases Sexual Activity and Desire in Surgically Menopausal Women with Hypoactive Sexual Desire Disorder. Journal of Clinical Endocrinology and Metabolism $2005905226-5233$.

39 Arlt W. Dehydroepiandrosterone replacement therapy. Seminars in Reproductive Medicine 200422 379-388.

40 Young J, Couzinet B, Nahoul K, Brailly S, Chanson P, Baulieu EE \& Schaison G. Panhypopituitarism as a model to study the metabolism of dehydroepiandrosterone (DHEA) in humans. Journal of Clinical Endocrinology and Metabolism 199782 2578-2585.

41 Arlt W, Callies F, van Vlijmen JC, Koehler I, Reincke M, Bidlingmaier M, Huebler D, Oettel M, Ernst M, Schulte HM \& Allolio B. Dehydroepiandrosterone replacement in women with adrenal insufficiency. New England Journal of Medicine 1999341 1013-1020.

42 Parasrampuria J, Schwartz K \& Petesch R. Quality control of dehydroepiandrosterone dietary supplement products. Journal of the American Medical Association 19982801565.

43 Lovas K, Loge JH \& Husebye ES. Subjective health status in Norwegian patients with Addison's disease. Clinical Endocrinology $20025 \mathbf{6} 581-588$.

44 Hunt PJ, Gurnell EM, Huppert FA, Richards C, Prevost AT, Wass JA, Herbert J \& Chatterjee VK. Improvement in mood and fatigue after dehydroepiandrosterone replacement in Addison's disease in a randomized, double blind trial. Journal of Clinical Endocrinology and Metabolism 200085 4650-4656.

45 Johannsson G, Burman P, Wiren L, Engstrom BE, Nilsson AG, Ottosson M, Jonsson B, Bengtsson BA \& Karlsson FA. Low dose dehydroepiandrosterone affects behavior in hypopituitary androgen-deficient women: a placebo-controlled trial. Journal of Clinical Endocrinology and Metabolism 200287 2046-2052.

46 Barnhart KT, Freeman E, Grisso JA, Rader DJ, Sammel M, Kapoor S \& Nestler JE. The effect of dehydroepiandrosterone supplementation to symptomatic perimenopausal women on serum endocrine profiles, lipid parameters, and health-related quality of life. Journal of Clinical Endocrinology and Metabolism $1999 \mathbf{8 4}$ 3896-3902.

47 Bloch M, Schmidt PJ, Danaceau MA, Adams LF \& Rubinow DR. Dehydroepiandrosterone treatment of midlife dysthymia. Biological Psychiatry $1999451533-1541$.

48 Schmidt PJ, Daly RC, Bloch M, Smith MJ, Danaceau MA, St Clair LS, Murphy JH, Haq N \& Rubinow DR. Dehydroepiandrosterone monotherapy in midlife-onset major and minor depression. Archives of General Psychiatry 200562 154-162.

49 Baulieu EE, Thomas G, Legrain S, Lahlou N, Roger M, Debuire B, Faucounau V, Girard L, Hervy MP, Latour F, Leaud MC, Mokrane A, Pitti-Ferrandi H, Trivalle C, de Lacharriere O, Nouveau S, Rakoto-Arison B, Souberbielle JC, Raison J, Le Bouc Y, Raynaud A, Girerd X \& Forette F. Dehydroepiandrosterone (DHEA), DHEA sulfate, and aging: contribution of the DHEAge Study to a sociobiomedical issue. Proceedings of the National Academy of Sciences USA 200097 4279-4284.

50 Dhatariya K, Bigelow ML \& Nair KS. Effect of dehydroepiandrosterone replacement on insulin sensitivity and lipids in hypoadrenal women. Diabetes $2005 \mathbf{5 4} 765-769$.

51 Villareal DT \& Holloszy JO. Effect of DHEA on abdominal fat and insulin action in elderly women and men: a randomized controlled trial. Journal of the American Medical Association 2004 292 2243-2248.

52 Watts NB, Notelovitz M, Timmons MC, Addison WA, Wiita B \& Downey LJ. Comparison of oral estrogens and estrogens plus androgen on bone mineral density, menopausal symptoms, and lipid-lipoprotein profiles in surgical menopause. Obstetrics and Gynaecology 199585 529-537. 
53 Raisz LG, Wiita B, Artis A, Bowen A, Schwartz S, Trahiotis M, Shoukri K \& Smith J. Comparison of the effects of estrogen alone and estrogen plus androgen on biochemical markers of bone formation and resorption in postmenopausal women. Journal of Clinical Endocrinology and Metabolism $19968137-43$.

54 Miller K, Corcoran C, Armstrong C, Caramelli K, Anderson E, Cotton D, Basgoz N, Hirschhorn L, Tuomala R, Schoenfeld D, Daugherty C, Mazer N \& Grinspoon S. Transdermal testosterone administration in women with acquired immunodeficiency syndrome wasting: a pilot study. Journal of Clinical Endocrinology and Metabolism $1998 \mathbf{8 3} 2717-2725$.

55 Callies F, Fassnacht M, van Vlijmen JC, Koehler I, Huebler D, Seibel MJ, Arlt W \& Allolio B. Dehydroepiandrosterone replacement in women with adrenal insufficiency: effects on body composition, serum leptin, bone turnover, and exercise capacity. Journal of Clinical Endocrinology and Metabolism $2001 \mathbf{8 6}$ 1968-1972.

56 Lovas K, Gebre-Medhin G, Trovik TS, Fougner KJ, Uhlving S, Nedrebo BG, Myking OL, Kampe O \& Husebye ES. Replacement of dehydroepiandrosterone in adrenal failure: no benefit for subjective health status and sexuality in a 9-month, randomized, parallel group clinical trial. Journal of Clinical Endocrinology and Metabolism $2003 \mathbf{8 8} 1112-1118$.

57 Morales AJ, Nolan JJ, Nelson JC \& Yen SS. Effects of replacement dose of dehydroepiandrosterone in men and women of advancing age. Journal of Clinical Endocrinology and Metabolism $1994 \mathbf{7 8}$ $1360-1367$.

58 Yen SS, Morales AJ \& Khorram O. Replacement of DHEA in aging men and women. Potential remedial effects. Annals of the New York Academy of Sciences $1995 \mathbf{7 7 4} 128-142$.

59 Morales AJ, Haubrich RH, Hwang JY, Asakura H \& Yen SS. The effect of six months treatment with a $100 \mathrm{mg}$ daily dose of dehydroepiandrosterone (DHEA) on circulating sex steroids, body composition and muscle strength in age-advanced men and women. Clinical Endocrinology $1998 \mathbf{4 9} 421$-432.

60 Casson PR, Santoro N, Elkind-Hirsch K, Carson SA, Hornsby PJ, Abraham G \& Buster JE. Postmenopausal dehydroepiandrosterone administration increases free insulin-like growth factor-I and decreases high-density lipoprotein: a six-month trial. Fertility $\mathcal{E}$ Sterility 199870 107-110.

61 Lasco A, Frisina N, Morabito N, Gaudio A, Morini E, Trifiletti A, Basile G, Nicita-Mauro V \& Cucinotta D. Metabolic effects of dehydroepiandrosterone replacement therapy in postmenopausal women. European Journal of Endocrinology 2001145 457-461.

Received 12 September 2005

Accepted 26 September 2005 